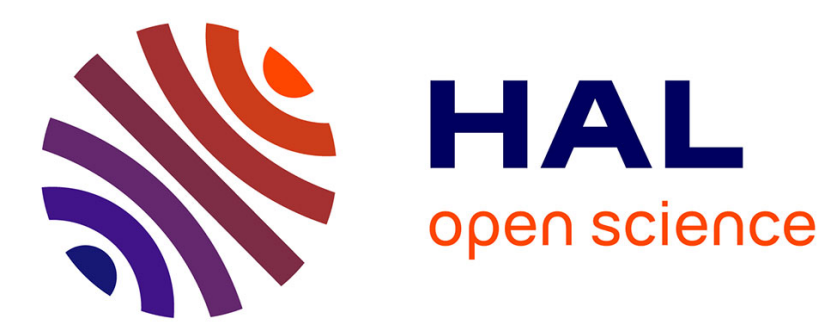

\title{
Comparative study of methodologies to measure in situ the intertidal benthic community metabolism during immersion
}

Vincent Ouisse, Aline Migné, Dominique Davoult

\section{To cite this version:}

Vincent Ouisse, Aline Migné, Dominique Davoult. Comparative study of methodologies to measure in situ the intertidal benthic community metabolism during immersion. Estuarine, Coastal and Shelf Science, 2014, 136, pp.19 - 25. 10.1016/j.ecss.2013.10.032 . hal-01097252

\section{HAL Id: hal-01097252 https://hal.sorbonne-universite.fr/hal-01097252}

Submitted on 19 Dec 2014

HAL is a multi-disciplinary open access archive for the deposit and dissemination of scientific research documents, whether they are published or not. The documents may come from teaching and research institutions in France or abroad, or from public or private research centers.
L'archive ouverte pluridisciplinaire HAL, est destinée au dépôt et à la diffusion de documents scientifiques de niveau recherche, publiés ou non, émanant des établissements d'enseignement et de recherche français ou étrangers, des laboratoires publics ou privés. 
Comparative study of methodologies to measure in situ the intertidal benthic community metabolism during immersion

Vincent Ouisse $^{1,2^{*}}$, Aline Migné ${ }^{1,2}$, Dominique Davoult ${ }^{1,2}$

1 - UPMC Univ Paris 06, UMR7144, Roscoff, France.

2 - CNRS, UMR 7144, Equipe Réseaux Trophiques et Production Benthique, Station

Biologique, Place Georges Teissier, BP 74, 29682, Roscoff Cedex. France.

* : Corresponding author : V. Ouisse

Email : vincent.ouisse@ifremer.fr

Tel: ( +33)4 99573283

Fax: ( +33)4 99573296

Present address : Ifremer, LER-LR, Avenue Jean Monnet, CS 30171, F-34203, France 
Abstract

Methods used to estimate community primary production and respiration in intertidal environment are still subject of controversy. Underwater community respiration (CR), net production (NCP) were calculated from simultaneous in situ measures of change in oxygen $\left(\mathrm{O}_{2}\right)$, dissolved inorganic carbon (DIC) and carbon dioxide $\left(\mathrm{CO}_{2}\right)$ concentration in benthic chambers performed in February, April, July and November on a Zostera noltii bed. The CRQ $\left(\mathrm{CR}_{\mathrm{DIC}} / \mathrm{CR}_{\mathrm{O} 2}\right)$ and $\mathrm{CPQ}\left(\mathrm{NCP}_{\mathrm{O} 2} / \mathrm{NCP}_{\mathrm{DIC}}\right)$ varied between 0.15 and 3.07 and between 0.03 and 6.83, respectively. Carbon fluxes calculated from $\mathrm{CO}_{2}$ measurement were greatly underestimated, representing only 0.4 to $5.9 \%$ of fluxes estimated from DIC measurement. Indeed, $\mathrm{CO}_{2}$ or $\mathrm{HCO}_{3}{ }^{-}$input or uptake by seagrass community affect the proportions of all the chemical components of dissolved inorganic carbon (DIC, the sum of free dissolved $\mathrm{CO}_{2}$, carbonic acid $\mathrm{H}_{2} \mathrm{CO}_{3}$, bicarbonate and carbonate ions, $\mathrm{HCO}_{3}{ }^{-}$and $\mathrm{CO}_{3}{ }^{2-}$ ). Thus, $\mathrm{CO}_{2}$ method is not reliable. $\mathrm{O}_{2}$ measurement does not take into account anaerobic respiration through chemical oxidation and simultaneous $\mathrm{O}_{2}$ and DIC measurements should be favoured to calculate CRQ and CPQ which need to be discussed in marine environment at community scale. 


\section{INTRODUCTION}

Most of the in situ production studies of macrophytes have focused on the seasonal variations of macroalgae (e.g. Mann, 1972) or seagrass biomass (e.g. Auby and Labourg, 1996; Jacobs, 1979; Pérez-Lloréns and Niell, 1993). However, this approach targets a single species and measures the balance between biomass production by photosynthesis and losses by respiration and due to grazing and exportation integrated over the growing season. This does not allow for measurement of primary production at the community level and leads to a quite rough annual estimation of primary production. Closed benthic chambers were developed in order to measure community metabolism in sedimentary environments with only slight disruption of the system. This approach allows for repeatable in situ measurements over the year, integrating biological and physical interactions between species over short time intervals.

During the emersion period in the intertidal zone, community metabolism can be estimated by measuring $\mathrm{CO}_{2}$ concentration changes in the air headspace of a closed benthic chamber (Migné et al., 2002). $\mathrm{CO}_{2}$ concentrations in air (expressed in ppm) are measured with a $\mathrm{CO}_{2}$ infrared gas analyzer. Depending on the community response intensity, the incubation duration can be very short $(<15 \mathrm{~min})$, which allows the estimation of primary production and respiration. This method has been used in unvegetated sediments (e.g. Davoult et al., 2009), in seagrass beds (Ouisse et al., 2010) and also on rocky shores (Golléty et al., 2008). However, in intertidal habitats this method is limited to measurements during the emersion phase, when the sediment are directly exposed to the air.

For sediments submerged under water, the methods used to assess community metabolism in benthic chambers are all based on measuring the variations of the water column concentrations of either dissolved inorganic carbon (DIC, encompassing dissolved $\mathrm{CO}_{2}$, 
$\mathrm{HCO}_{3}{ }^{-}$and $\mathrm{CO}_{3}{ }^{2-}$ ) or dissolved oxygen. The $\mathrm{O}_{2}$ method (Winkler titration or probe) is currently used in many marine ecosystems (e.g. Barrón et al., 2004; Buesa, 1977; Plus et al., 2001). It only measures aerobic respiration, which comprises the aerobic degradation of organic compounds and the re-oxidation of reduced products (e.g., sulfide, reduced metals, ammonium) produced by anaerobic metabolism. Changes in DIC, as calculated from $\mathrm{pH}$ and alkalinity variations, measure the balance of $\mathrm{CO}_{2}$ production and consumption, and therefore, integrate both aerobic and anaerobic processes. However, while the $\mathrm{pH}$ can be monitored with a probe in situ similarly as $\mathrm{O}_{2}$, the alkalinity measurements require the sampling of water for a titration procedure that can be considered unwieldy.

Recently, Silva et al. (2008) suggested a method to monitor the $\mathrm{CO}_{2}$ evolution inside the closed incubation chamber during both immersion and emersion as an approach to improve our understanding of carbon cycling in intertidal benthic communities. The proposed method has been criticized and prompted discussion in the literature with respect to the appropriateness for this application (Abril, 2009; Silva and Santos, 2009). Briefly, the method is performed as follows: during immersion, water from the chamber is recirculated by a peristaltic pump at the surface and flows through an equilibrator, which allows the concentration of $\mathrm{CO}_{2}$ to be continuously monitored in the gas phase by an infrared analyzer.

Using this method, Silva et al. (2008) measured a community metabolism greatly lower during immersion than during emersion in the Zostera noltii bed of the Ria Formosa Lagoon. These results were completely the opposite of the results described in two recently published studies for other Zostera noltii beds, which were based on DIC measurements during the immersion period and measurements of $\mathrm{CO}_{2}$ in air during the emersion periods. Thus, Clavier et al. (2011) and Ouisse et al. (2011), who studied the Z. noltii beds in the Banc d'Arguin and 
in Brittany, respectively, both measured up to 7 fold higher community metabolism during immersion than during emersion. Practically, $\mathrm{CO}_{2}$ represents only a small part of the DIC pool that is in dynamic equilibrium with the other forms of inorganic carbon in seawater. The uptake or release of one of the DIC components during photosynthesis and respiration, respectively, will shift the equilibrium and thus affect the proportions of all the others (see Fig. 1 in Abril, 2009). Thus, investigators must either take care to measure sufficient chemical variables to fully characterize the carbon dioxide system, or directly measure total DIC (Dickson et al., 2007). Collectively, the discussion in the literature (Abril, 2009; Silva and Santos, 2009) and the contrasting results obtained according the different methods (Silva et al., 2008; Clavier et al., 2011; Ouisse et al., (2011) clearly demonstrate that this is an important subject of controversy which can lead to opposite conclusions on the role of benthic communities in the carbon cycle in coastal areas. Nevertheless, to the best of our knowledge there is no experimental study where these two methods (DIC and $\mathrm{CO}_{2}$ ) have been applied simultaneously and compared. In this context, the main aim of this study was to evaluate simultaneously these two methodologies during in situ measurements of intertidal community production and respiration during immersion in seagrass beds. In addition, considering that temperature is one of the main parameters controlling community metabolism (Touchette \& Burkholder 2000 for review) and also influences the partitioning of $\mathrm{CO}_{2}$ in the DIC pool, we performed our analyses during different seasons.

\section{MATERIAL AND METHODS}

\subsection{Study site}

The study was carried out on an intertidal Zostera noltii bed located near Roscoff $\left(48^{\circ} \mathrm{N} 41.735,3^{\circ} \mathrm{W} 57.653\right.$, Western English Channel, France). The seagrass bed (covering 
around $\left.700 \mathrm{~m}^{2}\right)$ is located below the mean low water neap tide level (3.30 m above chart datum) and is exposed to high daily water level variations, which influence light availability.

\subsection{Benthic chamber}

Three benthic chambers were installed by SCUBA-diving. Each was made of a crown wheel of stainless steel and an acrylic hemisphere, covering a surface area of $0.071 \mathrm{~m}^{2}$ and enclosing a volume of $10.5 \mathrm{~L}$ of water. The crown wheels were pushed down to $10 \mathrm{~cm}$ sediment depth and sealed with clear (for net community production measurements, NCP) or dark (for community respiration measurements, CR) hemispheres using wing nuts. Watertightness was ensured by a silicone seal placed in a PVC groove at the top of the crown wheel. One of the three chambers was linked to the boat (for the continuous measurement of $\mathrm{O}_{2}, \mathrm{pH}$ and $\mathrm{CO}_{2}$ ), flowing being ensured by a peristaltic pump (flow-through chamber). The seawater inside the two other chambers was mixed by autonomous stirrers. A sample of seawater was withdrawn from each of the three chambers by $100 \mathrm{ml}$ syringes at the beginning and at the end of incubations (2-point method). Dissolved oxygen concentration and $\mathrm{pH}$ were immediately measured on a subsample using a luminescent/optical dissolved oxygen probe with built-in temperature sensor (LDO101, accuracy $\pm 0.2 \mathrm{mg}^{-1}$ ) and a combination $\mathrm{pH}$ probe with a gelfilled double junction reference and built-in temperature sensor (PHC101, accuracy \pm 0.002 , NBS scale, previously calibrated). The rest of the sample was passed through a cellulose acetate membrane filter $(0.8 \mu \mathrm{m})$ and stored pending potentiometric laboratory determination of total alkalinity (Millero et al., 1993) on 3 subsamples of $20 \mathrm{ml}$ the following day.

Dissolved oxygen concentration, $\mathrm{pH}$ and $\mathrm{CO}_{2}$ concentration were also continuously monitored inside the flow-through chamber. $\mathrm{O}_{2}$ concentration and $\mathrm{pH}$ were measured using LDO101 and PHC101 probes and data were recorded with a 1 min frequency using a multi data logger (HQ40D, Hach Lange Ltd, Loveland USA). $\mathrm{CO}_{2}$ concentration was measured 
using coupled closed water and air circuits, following Silva et al (2008). The gas exchange column (MiniModule ${ }^{\circledR}$ Membrane Contactor, Celgard, USA) allows the water pumped from the chamber to equilibrate the gas $\left(\mathrm{CO}_{2}\right)$ partial pressure between air and water. Changes in air $\mathrm{CO}_{2}$ concentration (ppm) were measured with a $\mathrm{CO}_{2}$ infrared gas analyzer ( $\left.\mathrm{LiCor} \mathrm{Li}-800\right)$ and data were recorded (data logger, LiCor Li-1400) with a $15 \mathrm{~s}$ frequency.

\subsection{Sampling strategy}

Carbon and oxygen fluxes were measured over an immersion period during spring tides in April, July and November 2009 and February 2010. On each occasion, short incubations (ca 45-60 $\min$ ) were performed simultaneously in the 3 benthic chambers: $n$ successive incubations at ambient light ( $n=1$ in February, 3 in April, 4 in July and 2 in November) to measure NCP and one incubation in darkness on the next incoming tide to measure CR. Benthic chambers were opened between successive incubations to restore ambient conditions but crown wheels were maintained at the same places.

Incident photosynthetically available radiation ( $\mu$ mol quanta $\left.\mathrm{m}^{-2} \mathrm{~s}^{-1}\right)$ was measured near the benthic chambers using an ultra-miniature MDS-MKV/L sensor (Alec Electronics ${ }^{\mathrm{TM}}$ ) and was recorded with a 1 min frequency.

\subsection{Community respiration and production calculation}

For the three benthic chambers, community respiration (CR, dark incubation) and net production rates ( $\mathrm{NCP}$, light incubation) were estimated from the difference between final and initial concentrations in either dissolved inorganic carbon (DIC) or $\mathrm{O}_{2}$ concentrations, both corrected for temperature change. CR and NCP were expressed in mmol m $\mathrm{m}^{-2} \mathrm{~h}^{-1}$. 
The DIC concentrations were calculated from the $\mathrm{pH}$, total alkalinity (TA), temperature and salinity using $\mathrm{CO}_{2}$ sys (calculation routine in MS Excel, Pierrot et al., 2006), the dissociation constant from Mehrbach et al. (1973) and refit by Dickson and Millero (1987). Total alkalinity (TA) did not differ between the beginning and the end of each incubation (Wilcoxon paired test, $\mathrm{n}=12, \mathrm{p}=0.10$ and $\mathrm{n}=11, \mathrm{p}=0.45$ for dark and last light incubations, respectively).

In the benthic chamber equipped with flow-through gas equilibrator and meters, $\mathrm{pH}, \mathrm{O}_{2}$ and $\mathrm{CO}_{2}$ changes were also calculated as the slopes of the linear regressions between each measured parameter and incubation time. $\mathrm{CO}_{2}$ concentrations in air were converted to $\mathrm{CO}_{2}$ concentrations in water using the solubility coefficients given by Weiss (1974). The theoretical part of dissolved $\mathrm{CO}_{2}$ in DIC pool was also calculated using $\mathrm{CO} 2$ sys (Pierrot et al., 2006).

Differences between carbon community fluxes estimated from $\mathrm{CO}_{2}$ measured and calculated and differences between 2-point and continuous estimation of DIC and oxygen fluxes were tested using Wilcoxon paired tests on independent observations (CR and highest NCP fluxes).

Mean community respiratory $\left(\mathrm{CRQ}=\mathrm{CR}_{\mathrm{DIC}} / \mathrm{CR}_{\mathrm{O} 2}\right)$ and photosynthetic $(\mathrm{CPQ}=$ $\mathrm{NCP}_{\mathrm{O} 2} / \mathrm{NCP}_{\text {DIC }}$ ) quotients were calculated as the slope of the regression lines between $\mathrm{CR}_{\mathrm{DIC}}$ and $\mathrm{CR}_{\mathrm{O} 2}$ and between $\mathrm{NCP}_{\mathrm{O} 2}$ and $\mathrm{NCP}_{\mathrm{DIC}}$ respectively using only independent observations (CR and highest NCP fluxes estimated from the 2-point method in the three benthic chambers). Since both variables were affected by natural variability and measurement errors and were not independent of the other, the geometric mean regression was applied (Ricker, 1973) to calculate the mean and standard deviation. The regressions have been forced through 
the origin since their intercepts were not significantly different from zero (test based on Student's law).

\section{RESULTS}

The time courses of $\mathrm{pH}$ and $\mathrm{O}_{2}$ concentration showed that these variables varied linearly with time during the incubations (see an example in Fig. 1). On the whole, the continuous and 2point methods provided similar estimations of fluxes in the flow-through chamber for both DIC and $\mathrm{O}_{2}$ (Fig. 2). The Wilcoxon paired test performed on independent observations showed no significant differences $(\mathrm{p}>0.05)$ either for DIC or oxygen fluxes.

Carbon and oxygen fluxes estimated by the 2-point method were similar in the three chambers (Fig. 3). Carbon and oxygen fluxes highlighted quite similar trend but with different magnitude and the average ratio between oxygen and carbon fluxes did not depart from the ratio 1:1 (Fig. 4). The community respiratory quotient $\left(\mathrm{CR}_{\mathrm{DIC}} / \mathrm{CR}_{\mathrm{O} 2}\right)$ varied from 0.15 to 3.07 and the mean was $0.95( \pm 0.22, \mathrm{n}=12)$. The absolute value of $\mathrm{NCP}_{\text {DIC }}$ was always higher than the $\mathrm{NCP}_{\mathrm{O} 2}$ and the community photosynthetic quotient $\left(\mathrm{NCP}_{\mathrm{O} 2} / \mathrm{NCP}_{\mathrm{DIC}}\right)$ varied from 0.03 in July to 6.83 in April (exceptional value) and the mean calculated on independent observations (i.e. one incubation per immersion period) was $0.42 \pm 0.27(\mathrm{n}=11)$.

For each sampling date, the metabolism was greatly lower when estimated from $\mathrm{CO}_{2}$ concentration measurements, representing only from 0.4 to $5.9 \%$ of the fluxes estimated by DIC measurements (Fig. 5 and Table 1). The carbon flux underestimations from the in situ $\mathrm{CO}_{2}$ direct measurements were not different than expected from calculated $\mathrm{CO}_{2}{ }^{(\mathrm{t})}$ rates (Wilcoxon paired test, $\mathrm{n}=4, \mathrm{p}=0.25$ and $\mathrm{n}=4, \mathrm{p}=0.63$ for dark and last light incubations, respectively). 


\section{DISCUSSION}

\subsection{Two-point samplings versus continuous measurements}

NCP and CR calculated from measurements at the beginning and the end in the flow-through benthic chamber were similar to those calculated from continuous measurements. This is explained by the fact that $\mathrm{pH}$ and $\mathrm{O}_{2}$ concentration varied linearly with time as the incubation time was short enough to prevent large changes in environmental conditions. Indeed, a longer duration of enclosure can potentially lead to $\mathrm{CO}_{2}$ depletion or severe $\mathrm{O}_{2}$ oversaturation which might inhibit photosynthesis (Noël et al., 2010) and enhance photorespiration (Heber et al., 1996). Furthermore, prolonged enclosure may induce temperature increase that might enhance respiration (del Giorgio and Williams, 2005). Although continuous $\mathrm{pH}, \mathrm{O}_{2}$ and temperature measurements are recommended, for short incubations, the measure of these variables only at the beginning and at the end of the incubation is often acceptable to obtain a correct measure of the rates of the community metabolism. However, the length of incubation periods that can lead to non-linear behaviour in time courses depends on the community structure isolated in the chamber. Therefore, it is important to check the appropriateness of the length of the incubation period prior to applying two-point measurements.

\subsection{Flow-through vs. stirrer motion}

Water motion is known to play an important role in controlling the rates of benthic metabolism by modifying the diffuse boundary layer and this has been studied for seagrasses (Larkum et al., 1989; (Fonseca and Kenworthy, 1987). In the present study, two different methods have been used to ensure water motion inside the benthic chambers (pumping circuit or stirrer), but the water flow was not measured. However, as the $\mathrm{O}_{2}$ and DIC fluxes were 
similar in the two types of benthic chambers, we conclude that both type of mixing were equivalent and probably the interior flow velocities were comparable.

\subsection{Oxygen vs DIC measurements}

The annual mean CRQ is in the range of values reported in the literature for seagrass beds (Barrón et al., 2006; Clavier et al., 2011). CRQ can vary where aerobic and anaerobic heterotrophic and autotrophic organisms co-exist, such as in the sediments of the seagrass beds. Organic matter decomposition with a concurrent $\mathrm{CO}_{2}$ production can occur without oxygen as the terminal electron acceptor, because this process may proceed through pathways of nitrate, manganese, iron and sulfate respiration (Jorgensen, 1977), while fermentation processes also produce $\mathrm{CO}_{2}$ without oxygen uptake. The annual mean CPQ is also in the range of literature data for marine algae (Burris, 1981) and for seagrass communities (Barrón et al., 2006). Although Zostera noltii may have a C4-like metabolism with no photorespiration (Jiménez et al., 1987), benthic microalgae from the sediment and epiphytes may exhibit some photorespiration process. This process can favour primary producers by removing excess products of the light reaction (i.e., ATP, NADPH), and limiting damage to the photosynthetic apparatus during period of high dissolved $\mathrm{O}_{2}$ and low $\mathrm{CO}_{2}$ and under high light intensity (Heber et al., 1996). Photorespiration implies that at least 3 oxygen molecules will be consumed per molecule of carbon dioxide used, decreasing the CPQ at the community level. The imbalance between $\mathrm{O}_{2}$ and DIC can be also attributed to exchange between leaves and roots (Borum et al., 2006 and references therein) and to radial loss of $\mathrm{O}_{2}$ from roots into the rhizosphere (Ribaudo et al 2011). This process maintain oxic conditions around roots and may thus provide protection against accumulation of reduced toxic compounds from surrounding sediment (Marbà et al., 2006 and references therein). The importance of this transport varies 
seasonally, with a maximum in summer when sediment respiration rates are highest (Ribaudo et al., 2011).

Thus measuring $\mathrm{O}_{2}$ fluxes and assuming a community quotient equal to 1 can overestimate community carbon fluxes when photorespiration occurs or underestimate it when anaerobic metabolism or radial $\mathrm{O}_{2}$ loss occurs. Hence, for obtaining a complete picture of community metabolism $\mathrm{O}_{2}$ and DIC fluxes need to be measured simultaneously and CPQ and CRQ need to be interpreted in view of these above-mentioned processes.

\subsection{Calculation of community metabolism using dissolved $\mathrm{CO}_{2}$ versus DIC measurements}

During all samplings, the $\mathrm{NCP}_{\mathrm{CO} 2}$ and $\mathrm{CR}_{\mathrm{CO} 2}$ rates measured from monitoring dissolved $\mathrm{CO}_{2}$ concentrations were dramatically lower than their corresponding rates calculated from DIC measurements ( $\mathrm{NCP}_{\mathrm{DIC}}$ and $\mathrm{CR}_{\mathrm{DIC}}$, respectively). Thus, the rates measured from dissolved $\mathrm{CO}_{2}$ measurements only represented 0.4 to $5.9 \%$ of the DIC fluxes (Table 1 ). Hence, now with experimental data we clearly show that directly using in situ measures of dissolved $\mathrm{CO}_{2}$ for calculating carbon fluxes results in severe underestimation and thus confirm the theoretical considerations described by Abril (2009). As a matter of fact, the rates calculated from variations of dissolved $\mathrm{CO}_{2}\left(\mathrm{NCP}_{\mathrm{CO} 2}\right.$ and $\left.\mathrm{CR}_{\mathrm{CO} 2}\right)$ were very similar to the theoretically expected $\mathrm{CO}_{2}{ }^{(\mathrm{t})}$ rates, which correspond to the predicted rates of variation of dissolved $\mathrm{CO}_{2}$ based on the corresponding $\mathrm{NCP}_{\mathrm{DIC}}$ or $\mathrm{CR}_{\mathrm{DIC}}$ values and considering the theoretical proportion of $\mathrm{CO}_{2}$ in DIC according $\mathrm{pH}$ and temperature. This is striking even if we consider that $\mathrm{CO}_{2}$ concentration was measured at the surface without taking into account the effect of pressure changes with the tide nor the temperature difference between water and the equilibrator (Takahashi et al., 1993), and the $\mathrm{CO}_{2}$ removal efficiency is approximately $75 \%$ according to the manufacturer equilibrator's data. When the variations of dissolved $\mathrm{CO}_{2}$ 
observed in the present study would be used as a direct proxy for community metabolism, one might suppose the community metabolism during immersion to be dramatically lower than during emersion, as was concluded by Silva et al. (2008) for the Z. noltii beds in the Ria Formosa Lagoon. However, this is clearly not correct due to the problem of severe underestimation. Actually at the same site in our previous study using measurements of DIC during and $\mathrm{CO}_{2}$ concentrations in air during emersion we showed that community metabolism was estimated to be 7 fold higher during immersion than emersion in this Zostera noltii bed (Ouisse et al., 2011). This was-attributed to a possible nutrient limitation and an important self-shading of the community by seagrass leaves during emersion. Indeed, the leaf superimposition preserved the community against desiccation but decreased the capacity to harvest light.

While IRGA technique (direct $\mathrm{CO}_{2}$ measure) is sensitive and has been proved to be a powerful method to investigate community metabolism during emersion in many intertidal studies in seagrass bed (Ouisse et al., 2010), in rocky shore (Golléty et al., 2008) or in others sediment systems (e.g. Davoult et al., 2009; Hubas et al., 2006; Migné et al., 2011; Migné et al., 2004), its utilization in coupled water-air circuit greatly underestimates community metabolism during immersion. The carbon fluxes reported under submerged conditions by Silva et al. (2008) using direct $\mathrm{CO}_{2}$ measurements need to be reassessed by coupling these measures with measures of $\mathrm{pH}$ or alkalinity in order to describe the carbon dioxide system and estimate the DIC fluxes during immersion periods.

\section{CONCLUSIONS}

Incubations in closed benthic chambers take are instrumental for measuring community metabolism as it takes the interactions between species into account under natural conditions. This comparative study highlights that the two-point sampling at the beginning and end of the 
incubation is an adequate method to measure the community fluxes during short incubations. It also confirms that the continuous measure of dissolved $\mathrm{CO}_{2}$ alone (i.e. without $\mathrm{pH}$ or alkalinity) is inappropriate to assess carbon community fluxes in marine environments during immersion and need to be combined with alkalinity or $\mathrm{pH}$ to achieve carbon fluxes. Even if the $\mathrm{O}_{2}$ method seems to be handy and easy to use, the assumption of CRQ or CPQ equal to 1 can lead to misinterpretation of carbon fluxes in coastal environment. Oxygen and DIC methods are complementary and need to be used simultaneously to discuss CRQ and CPQ values. The difference over the course of the year between measured and theoretically assumed values of these quotients (ratio of 1:1) and the total alkalinity variations can give some information about anaerobic mineralization of organic matter in the seagrass bed.

\section{ACKNOWLEDGMENTS}

This This study forms part of the Ph.D thesis of V. Ouisse and was financially supported by the "Ministère de l'Enseignement Supérieur et de la Recherche". The authors would like to thank Y. Bozec for his knowledge of carbon flux systems, the Service Mer et Observation E. Macé M. Boivin and A. Bonnefoy for their participation in field experiment, L. Noël and R. de Wit for improving English redaction.

\section{REFERENCES}

Abril, G., 2009. Comment on: "Underwater measurements of carbon dioxide evolution in marine plant communities: A new method" by J. Silva and R. Santos [Estuarine, Coastal and Shelf Science 78 (2008) 827-830]. Estuarine, Coastal and Shelf Science 82, 357-360. Auby, I., Labourg, P.-J., 1996. Seasonal dynamics of Zostera noltii Hornem. in the bay of Arcachon (France). Journal of Sea Research 35, 269-277.

Barrón, C., Duarte, C., Frankignoulle, M., Borges, A., 2006. Organic carbon metabolism and carbonate dynamics in a Mediterranean seagrass (Posidonia oceanica) meadow. Estuaries and Coasts 29, 417-426.

Barrón, C., Marba, N., Terrados, J., Kennedy, H., Duarte, C.M., 2004. Community metabolism and carbon budget along a gradient of seagrass (Cymodocea nodosa) colonization. Limnology and Oceanography 49, 1642-1651. 
Borum, J., Sand-Jensen, K., Binzer, T., Pedersen, O., Greve, T.M., 2006. Oxygen Movement in Seagrasses, in: Larkum, A.W.D., Orth, R.J., Duarte, C.M. (Eds.), Seagrasses: Biology, ecology and conservation. Springer, Dordrecht, pp. 255-270.

Buesa, R.J., 1977. Photosynthesis and respiration of some tropical marine plants. Aquatic Botany 3, 203-216.

Burris, J.E., 1981. Effects of oxygen and inorganic carbon concentrations on the photosynthetic quotients of marine algae. Marine Biology 65, 215-219.

Clavier, J., Chauvaud, L., Carlier, A., Amice, E., Van der Geest, M., Labrosse, P., Diagne, A., Hily, C., 2011. Aerial and underwater carbon metabolism of a Zostera noltii seagrass bed in the Banc d'Arguin, Mauritania. Aquatic Botany 95, 24-30.

Davoult, D., Migné, A., Créach, A., Gévaert, F., Hubas, C., Spilmont, N., Boucher, G., 2009. Spatio-temporal variability of intertidal benthic primary production and respiration in the western part of the Mont Saint-Michel Bay (Western English Channel, France).

Hydrobiologia 620, 163-172.

del Giorgio, P.A., Williams, P.J., 2005. Respiration in Aquatic Ecosystems. Oxford University Press, Oxford.

Dickson, A.G., Millero, F.J., 1987. A comparison of the equilibrium constants for the dissociation of carbonic acid in seawater media. Deep Sea Research 34, 1733-1743. Dickson, A.G., Sabine, C.L., Christian, J.R., 2007. Guide to best practices for ocean $\mathrm{CO}_{2}$ measurements. PICES Special 3.

Fonseca, M.S., Kenworthy, W.J., 1987. Effects of current on photosynthesis and distribution of seagrasses. Aquatic Botany 27, 59-78.

Golléty, C., Migné, A., Davoult, D., 2008. Benthic metabolism on a sheltered rocky shore: role of the canopy in the carbon budget. Journal of Phycology 44, 1146-1153.

Heber, U., Bligny, R., Streb, P., Douce, R., 1996. Photorespiration is essential for the protection of the photosynthetic apparatus of $\mathrm{C} 3$ plants against photoinactivation under sunlight. Botanica acta 109, 307-315.

Hubas, C., Davoult, D., Cariou, T., Artigas, L.P., 2006. Factors controlling benthic metabolism during low tide along a granulometric gradient in an intertidal bay (Roscoff Aber Bay, France). Marine Ecology Progress Series 316, 53-68.

Jacobs, R.P.W.M., 1979. Distribution and aspects of the production and biomass of eelgrass, Zostera marina L., at Roscoff, France. Aquatic Botany 7, 151-172.

Jiménez, C., Niell, F.X., Algarra, P., 1987. Photosynthetic adaptation of Zostera noltii Hornem. Aquatic Botany 29, 217-226.

Jorgensen, B.B., 1977. The sulfur cycle of a coastal marine sediment (Limfjorden, Denmark). Limnology and Oceanography 22, 814-832.

Mann, K.H., 1972. Ecological energetics of the sea-weed zone in a marine bay on the Atlantic coast of Canada. II. Productivity of the seaweeds. Marine Biology 14, 199-209.

Marbà , N., Holmer, M., Gacia, E., 2006. Seagrasses and Biogeochemistry, in: Larkum, A.W.D., Orth, R.J., Duarte, C.M. (Eds.), Seagrasses: Biology, ecology and conservation. Springer, Dordrecht, pp. 135-157.

Mehrbach, C., Culberson, C.H., Hawley, J.E., Pytkowicz, R.M., 1973. Measurement of of the apparent dissociation constants of carbonic acid in seawater at atmospheric pressure.

Limnology and Oceanography 18, 897-907.

Migné, A., Davoult, D., Spilmont, N., Menu, D., Boucher, G., Gattuso, J.-P., Rybarczyk, H., 2002. A closed-chamber $\mathrm{CO}_{2}$-flux method for estimating intertidal primary production and respiration under emersed conditions. Marine Biology 140, 865-869.

Migné, A., Ouisse, V., Hubas, C., Davoult, D., 2011. Freshwater seepages and ephemeral macroalgae proliferation in an intertidal bay: II Effect on benthic biomass and metabolim. Estuarine, Coastal and Shelf Science 92, 161-168. 
Migné, A., Spilmont, N., Davoult, D., 2004. In situ measurements of benthic primary production during emersion: seasonal variations and annual production in the Bay of Somme (eastern English Channel, France). Continental Shelf Research 24, 1437-1449.

Millero, F.J., Zhang, J.-Z., Lee, K., Campbell, D.M., 1993. Titration alkalinity of seawater. Marine Chemistry 44, 153-165.

Noël, L.M.L.J., Griffin, J.N., Thompson, R.C., Hawkins, S.J., Burrows, M.T., Crowe, T.P., Jenkins, S.R., 2010. Assessment of a field incubation method estimating primary productivity in rockpool communities. Estuarine, Coastal and Shelf Science 88, 153-159.

Ouisse, V., Migné, A., Davoult, D., 2010. Seasonal variations of community production, respiration and biomass of different primary producers in an intertidal Zostera noltii bed (Western English Channel, France). Hydrobiologia 649, 3-11.

Ouisse, V., Migné, A., Davoult, D., 2011. Community-level carbon flux variability over a tidal cycle in Zostera marina and Zostera noltii beds. Marine Ecology Progress Series 437, 79-87.

Pérez-Lloréns, J.L., Niell, F.X., 1993. Seasonal dynamics of biomass and nutrient content in the intertidal seagrass Zostera noltii Hornem. from Palmones River estuary, Spain. Aquatic Botany 46, 49-66.

Pierrot, D., Lewis, E., Wallace, D.W.R., 2006. MS Excel Program Developed for $\mathrm{CO}_{2}$ System Calculations, in: Carbon Dioxide Information Analysis Center, O.R.N.L., U.S

ORNL/CDIAC-105a (Ed.), Department of Energy, Oak Ridge, Tennessee.

Plus, M., Deslous-Paoli, J.-M., Auby, I., Dagault, F., 2001. Factors influencing primary production of seagrass beds (Zostera noltii Hornem.) in the Thau lagoon (French

Mediterranean coast). Journal of Experimental Marine Biology and Ecology 259, 63-84.

Ribaudo, C., Bartoli, M., Racchetti, E., Longhi, D., Viaroli, P., 2011. Seasonal fluxes of $\mathrm{O}_{2}$, DIC and $\mathrm{CH}_{4}$ in sediments with Vallisneria spiralis: indications for radial oxygen loss.

Aquatic Botany 94, 134-142.

Ricker, W.E., 1973. Linear regressions in fishery research. Journal of fisheries research board of canada 30, 409-434.

Silva, J., Feijóo, P., Santos, R., 2008. Underwater measurements of carbon dioxide evolution in marine plant communities: A new method. Estuarine, Coastal and Shelf Science 78, 827830.

Silva, J., Santos, R., 2009. Reply to comment of G. Abril on "Underwater measurements of carbon dioxide evolution in marine plant communities: A new method" by J. Silva and R.

Santos [Estuarine, Coastal and Shelf Science 78(2008) 827-830]. Estuarine, Coastal and Shelf Science 82, 361-362.

Takahashi, T., Olafsson , J., Goddard, J.G., Chipman, D.W., Sutherland, S.C., 1993. Seasonal variation of $\mathrm{CO}_{2}$ and nutrients in the high-latitude surface oceans: a comparative study.

Global Biogeochemistry Cycles 7, 843-878.

Weiss, R.F., 1974. Carbon dioxide in water and seawater: the solubility of a non-ideal gas. Marine Chemistry 2, 203-215. 

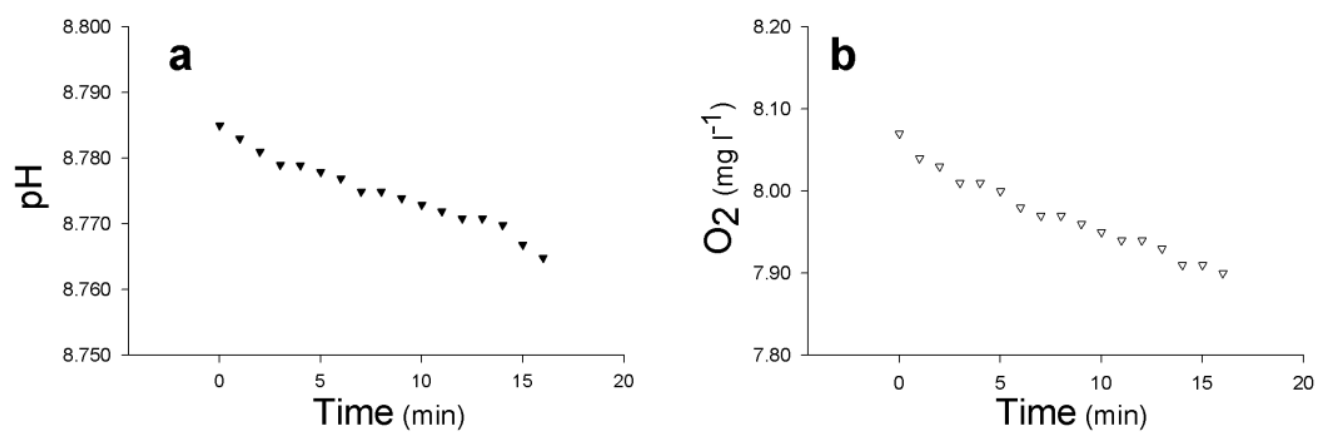

Figure 1: Examples of the time courses of (a) $\mathrm{pH}$ and (b) $\mathrm{O}_{2}$ concentration (in $\mathrm{mg}^{-1}$ ) during a dark incubation, both parameters have been corrected for temperature change.
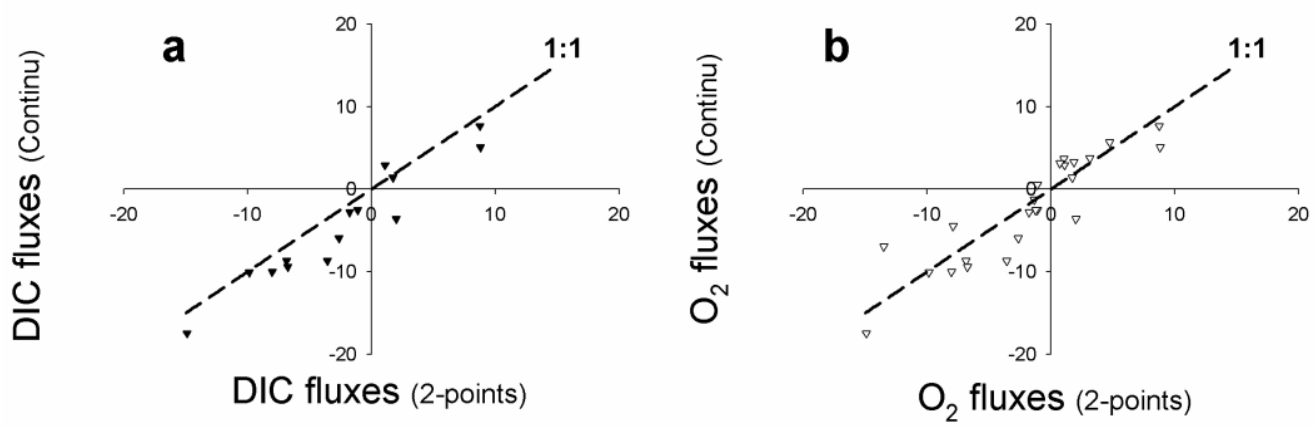

Figure 2: Comparison of (a) DIC (mmol m $\left.\mathrm{m}^{-2} \mathrm{~h}^{-1}\right)$ and (b) $\mathrm{O}_{2}\left(\mathrm{mmol} \mathrm{m}^{-2} \mathrm{~h}^{-1}\right)$ fluxes calculated from continuous monitoring and two-point methods in the flow-through chamber

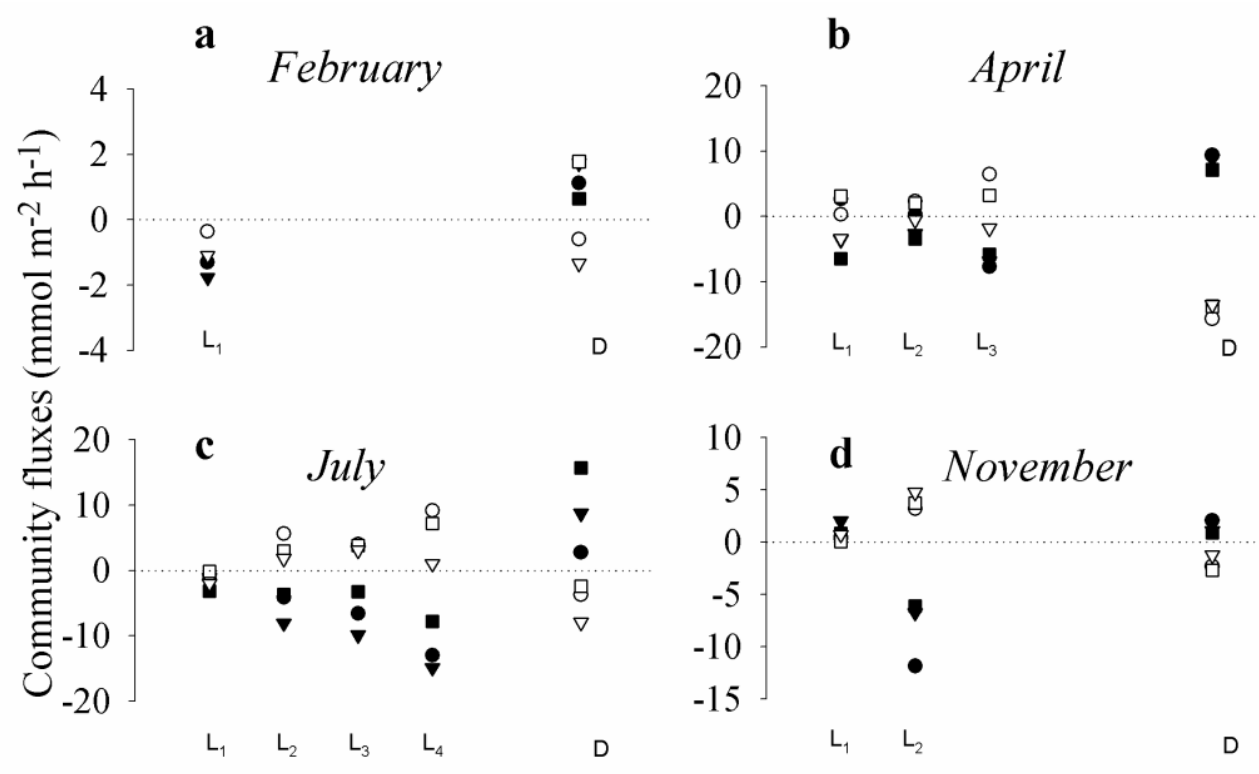

Figure 3: Community net production and respiration $\left(\mathrm{mmol} \mathrm{m}^{-2} \mathrm{~h}^{-1}\right)$ estimated from the twopoint method as DIC (closed symbol) and $\mathrm{O}_{2}$ (open symbol) fluxes in the three benthic chambers. The fluxes estimated in the flow-through benthic chamber are indicated by triangles. $\mathrm{L}_{1}, \mathrm{~L}_{2}, \mathrm{~L}_{3}, \mathrm{~L}_{4}$ and $\mathrm{D}$ indicate successive light and dark incubations in (a) February, (b) April, (c) July and (d) November. Light conditions during incubations are given in Table 1. 


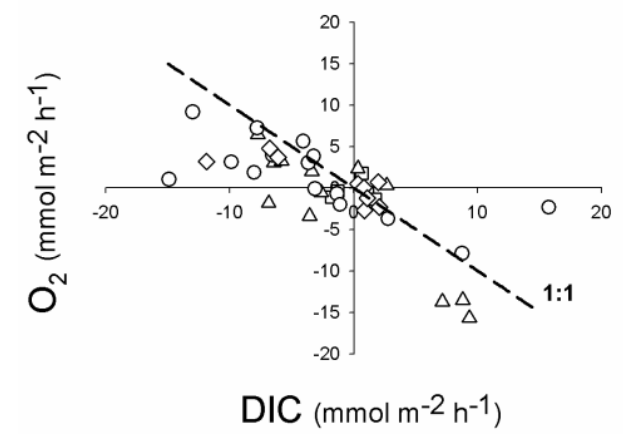

Figure 4: Cross-plot of $\mathrm{O}_{2}$ and DIC $\left(\mathrm{mmol} \mathrm{m}^{-2} \mathrm{~h}^{-1}\right)$ fluxes estimated from the 2-point method in the three benthic chambers in February (square), April (triangle), July (circle) and November (diamond).

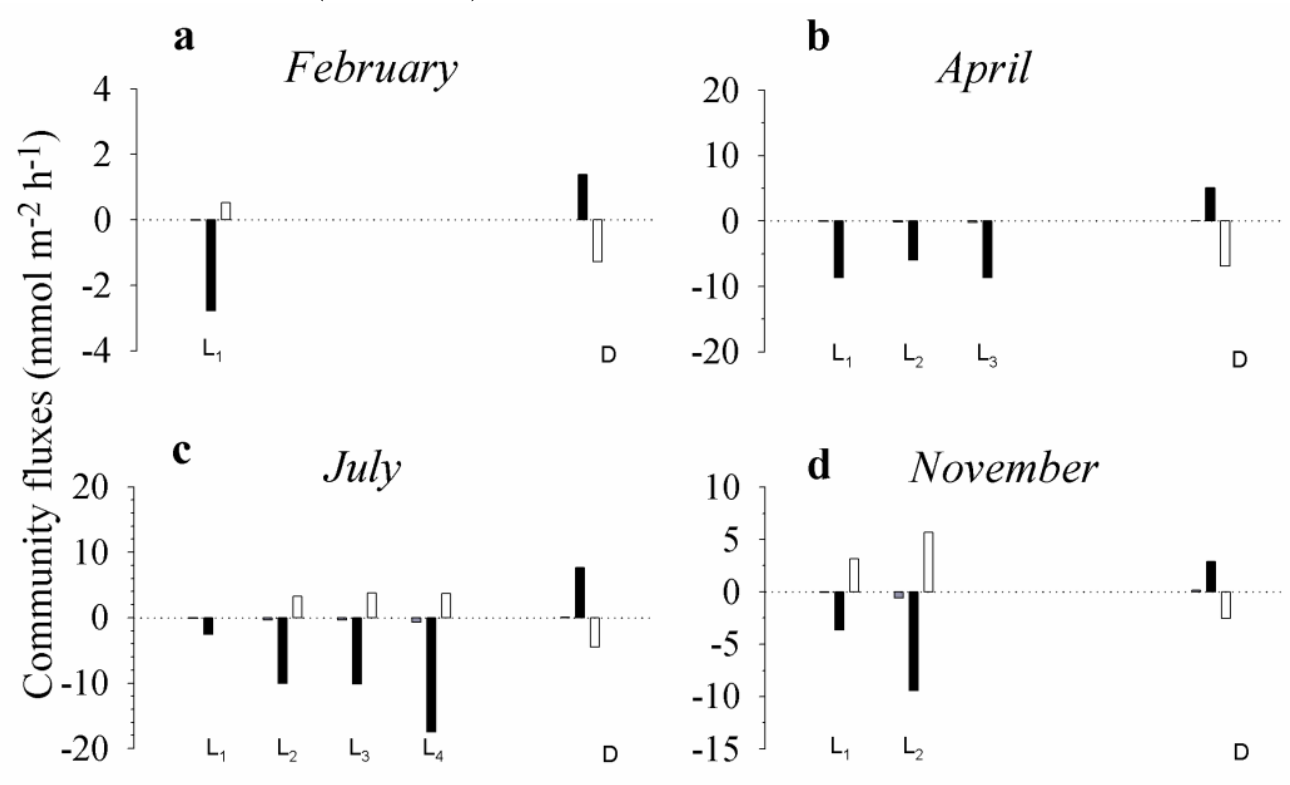

Figure 5: The community net production rates $\mathrm{NCP}_{\mathrm{CO} 2}$ (grey bars), $\mathrm{NCP}_{\mathrm{DIC}}$ (black bars) and $\mathrm{NCP}_{\mathrm{O} 2}$ (white bars) calculated from continuous measurements of $\mathrm{CO}_{2}, \mathrm{DIC}$, and $\mathrm{O}_{2}$, respectively in the flow-through benthic chamber incubated under ambient light conditions (see Table 1). The community respiration rates $\mathrm{CR}_{\mathrm{CO} 2}$ (grey bars), $\mathrm{CR}_{\mathrm{DIC}}$ (black bars) and $\mathrm{CR}_{\mathrm{O} 2}$ (white bars) calculated from continuous measurements of $\mathrm{CO}_{2}$, DIC, and $\mathrm{O}_{2}$, respectively in the flow-through benthic chamber during the dark conditions. $\mathrm{L}_{1}, \mathrm{~L}_{2}, \mathrm{~L}_{3}, \mathrm{~L}_{4}$ and $\mathrm{D}$ indicate successive light and dark incubations, respectively, during the measurements in (a) February, (b) April, (c) July and (d) November. Values and environmental conditions are presented in the Table 1. All rates are expressed in $\mathrm{mmol} \mathrm{m} \mathrm{m}^{-2} \mathrm{~h}^{-1}$ 


\begin{tabular}{|c|c|c|c|c|c|c|c|c|c|}
\hline Month & Date & & $\begin{array}{c}\text { Light exposure } \\
\text { mol quanta } \mathrm{m}^{-2} \mathrm{~s}^{-1}\end{array}$ & $\begin{array}{c}\text { Temperature } \\
{ }^{\circ} \mathrm{C} \\
\end{array}$ & Initial $\mathrm{pH}$ & DIC & $\begin{array}{l}\mathrm{CO}_{2}^{(\mathrm{t})} \\
\mathrm{mmol} \mathrm{m}\end{array}$ & $\begin{array}{l}\mathrm{CO}_{2} \\
2^{-2} h^{-1} \\
\end{array}$ & $\mathrm{O}_{2}$ \\
\hline \multicolumn{10}{|c|}{ February } \\
\hline & 02/13/09 09:30 AM & $\mathrm{L}_{1}$ & $118 \pm 60$ & $8.7 \pm 0.0$ & 7.950 & -2.77 & -0.45 & -0.02 & 0.52 \\
\hline & 02/13/09 11:30 AM & $\mathrm{D}$ & & $8.3 \pm 0.6$ & 8.275 & 1.39 & 0.08 & 0.01 & -1.28 \\
\hline \multicolumn{10}{|l|}{ April } \\
\hline & 04/24/09 09:00 AM & $\mathrm{L}_{1}$ & $81 \pm 18$ & $12.0 \pm 0.0$ & 8.269 & -8.66 & -0.35 & -0.03 & NA \\
\hline & 04/24/09 10:00 AM & $\mathrm{L}_{2}$ & $226 \pm 97$ & $12.1 \pm 0.1$ & 8.328 & -5.92 & -0.24 & -0.14 & NA \\
\hline & 04/24/09 10:45 AM & $\mathrm{L}_{3}$ & $482 \pm 128$ & $12.6 \pm 0.1$ & 8.380 & -8.67 & -0.30 & -0.26 & NA \\
\hline & 04/24/09 02:30 PM & $\mathrm{D}$ & & $14.5 \pm 0.7$ & 8.747 & 5.04 & 0.05 & 0.03 & -6.90 \\
\hline \multicolumn{10}{|l|}{ July } \\
\hline & 07/27/09 11:20 AM & $\mathrm{L}_{1}$ & $119 \pm 55$ & $16.1 \pm 0.1$ & 8.442 & -2.53 & -0.05 & -0.10 & NA \\
\hline & 07/27/09 12:30 PM & $\mathrm{L}_{2}$ & $244 \pm 58$ & $16.4 \pm 0.1$ & 8.470 & -10.02 & -0.16 & -0.36 & 3.26 \\
\hline & 07/27/09 01:20 PM & $\mathrm{L}_{3}$ & $297 \pm 173$ & $16.6 \pm 0.2$ & 8.464 & -10.09 & -0.19 & -0.36 & 3.74 \\
\hline & 07/27/09 02:15 PM & $\mathrm{L}_{4}$ & $1119 \pm 305$ & $18.5 \pm 0.3$ & 8.525 & -17.45 & -0.32 & -0.72 & 3.69 \\
\hline & 07/27/09 06:30 PM & $\mathrm{D}$ & & $18.3 \pm 0.3$ & 8.785 & 7.66 & 0.06 & 0.07 & -4.47 \\
\hline \multicolumn{10}{|c|}{ November } \\
\hline & $11 / 17 / 09$ 09:30 AM & $\mathrm{L}_{1}$ & $54 \pm 30$ & $12.3 \pm 0.1$ & 8.134 & -3.62 & -0.28 & -0.04 & 3.14 \\
\hline & $11 / 17 / 09$ 10:30 AM & $\mathrm{L}_{2}$ & $229 \pm 130$ & $12.4 \pm 0.1$ & 8.211 & -9.41 & -0.56 & -0.55 & 5.68 \\
\hline & $11 / 17 / 09$ 02:00 PM & $\mathrm{D}$ & & $13.1 \pm 0.1$ & 8.294 & 2.90 & 0.15 & 0.13 & -2.51 \\
\hline
\end{tabular}

Table 1: The community net production (NCP) and respiration rates (CR) measured during successive light $\left(\mathrm{L}_{1}, \mathrm{~L}_{2}, \mathrm{~L}_{3}, \mathrm{~L}_{4}\right)$ and dark incubations (D), respectively (cf. Fig. 5) in the flow-through benthic chamber in February, April, July and November. The DIC column lists $\mathrm{NCP}_{\text {DIC }}$ or $\mathrm{CR}_{\mathrm{DIC}}$-values calculated from variations of DIC. The $\mathrm{CO}_{2}{ }^{\left({ }^{(t)}\right.}$ column corresponds to a predicted rate of variation of dissolved $\mathrm{CO}_{2}$ based on $\mathrm{NCP}_{\text {DIC }}$ or $\mathrm{CR}_{\mathrm{DIC}}$-values and considering the theoretical proportion of $\mathrm{CO}_{2}$ in DIC according $\mathrm{pH}$ and temperature. The $\mathrm{CO}_{2}$ column lists $\mathrm{NCP}_{\mathrm{CO} 2}$ or $\mathrm{CR}_{\mathrm{CO} 2}$-values calculated directly from the measured variations of dissolved $\mathrm{CO}_{2}$. The $\mathrm{O}_{2}$ column lists $\mathrm{NCP}_{\mathrm{O} 2}$ or

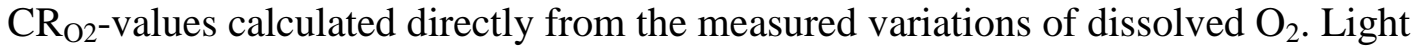
intensity (mean $\pm \mathrm{SD}$ ) near the benthic chamber and temperature (mean $\pm \mathrm{SD}$ ) inside the benthic chamber have measured for each incubation. NA indicates non available data. 